\title{
Supplemental Factors Including Those Associated with Anesthesiology for Respiratory Insufficiency after Thymectomy in Generalized Myasthenia Gravis
}

\author{
Hiroshi Kataoka Satoshi Ueno \\ Department of Neurology, Nara Medical University, Kashihara, Japan
}

Dear Sir,

We respond to five suggestions from the viewpoint of anesthesiologists regarding our article [1]. In 12 patients with myasthenia gravis (MG) who preoperatively received steroids $(17.8 \pm 3.1 \mathrm{mg} /$ day $)$, the steroid dose was decreased to $6.7 \pm 4.6 \mathrm{mg} /$ day (dose reduction, $11.5 \pm 4.7 \mathrm{mg} /$ day) at final follow-up (32.2 \pm 17.3 months), and 4 other patients received both steroids $(20,7$, 5 , and $10 \mathrm{mg} /$ day) and immunosuppressants. The decrease in the steroid dose might be attributed to significant reductions in postoperative serum antibodies binding to acetylcholine receptor (AchR$\mathrm{Ab}$ ) after both preoperative steroid use and thymectomy [1], thereby stabilizing the clinical status of MG. We used the term 'low-dose steroids' in the title because the dose was lower than that used in previous studies, but we consider the dosage of steroids in our study to be physiological and not low. As pointed out, the surgical technique, preoperative use of acetylcholinesterase, and preoperative respiratory function tests can have an impact on preoperative respiratory insufficiency (PRI). With regard to the surgical technique, the number of surgeons differed between the steroid use group (one surgeon) and the steroid nonuse group (four surgeons) [1]. The preoperative use of acetylcholinesterase, which can induce respiratory insufficiency [2], which was slightly but not significantly higher in the steroid nonuse group $(80 \%)$ than in the steroid use group (62\%). The preoperative vital capacity was also better in the steroid use group [1], but preoperative arterial blood gas analysis of patients with and without steroid use showed no difference in carbon dioxide $(41.1 \pm 4.4$ vs. $42.9 \pm 3.4 \mathrm{~mm} \mathrm{Hg}$, respectively) or oxygen $(81.5 \pm 10.8$ vs. $82.3 \pm 8.1 \mathrm{~mm} \mathrm{Hg}$, respectively).

Thank you for the important suggestions related to anesthesiology. Because this study included a retrospective review of patients without steroid use, we could not provide complete information. However, information on the steroid use group is shown in table 1 . As for narcotics, in 16 patients without steroid use for whom information on narcotic use was available, fentanil was used in all patients, and the total dose during surgery was $365.6 \pm 199.7$ $\mu \mathrm{g}$ (range 100 to $800 \mu \mathrm{g}$ ); remifentanil was used in two patients (1,150 and 4,019.4 $\mu \mathrm{g})$. In addition, one patient received ketamine (10 mg). A neuromuscular blocking agent was used in one patient (vecronium 1.3 $\mathrm{mg}$ ). While most patients who were given steroids received both fentanyl (326.7 \pm $137.4 \mu \mathrm{g})$ and remifentanil $(2,185.8 \pm$ $1,553.2 \mu \mathrm{g}$ ); two patients received recroni$\mathrm{um}$. When a neuromuscular blocking agent was injected, neuromuscular monitorization was done. The use of epidural analgesia decreased the need for postoperative ventilatory support [3]. Epidural analgesia was performed in some patients without steroid use, but detailed data are unavailable. In the three patients for whom data were available, epidural analgesia was administered postoperatively $(n=2)$ and intraoperatively $(\mathrm{n}=2)$, and repivacaine $(\mathrm{n}=$ $2)$, fentanyl $(n=2)$, droperidol $(n=1)$, or buprenorphine $(n=1)$ was used. Eleven patients with steroid use received postoperative epidural analgesia (table 1). The dosage

\section{KARGER 125}

(c) 2015 S. Karger AG, Base

0014-3022/15/0734-0195\$39.50/0
Dr. Kataoka and Satoshi Ueno Department of Neurology Nara Medical University 840 Shijo-cho, Kashihara, Nara 634-8522 (Japan)

E-Mail hk55@naramed-u.ac.jp and sueno@ naramed-u.ac.jp 
Table 1. Use of narcotics, neuromuscular blocking agents, and epidural analgesia in patients with myasthenia gravis who preoperatively received steroids

\begin{tabular}{|c|c|c|c|c|c|c|c|c|c|c|c|c|}
\hline \multirow[t]{2}{*}{ Patient } & \multicolumn{3}{|c|}{$\begin{array}{l}\text { Total dose of narcotics during } \\
\text { surgery }\end{array}$} & \multirow{2}{*}{$\begin{array}{l}\text { Neuromuscular } \\
\text { blocking agents } \\
\text { rocronium } \\
(\mathrm{mg})\end{array}$} & \multicolumn{8}{|c|}{ Epidural analgesia } \\
\hline & $\begin{array}{l}\text { fentanil } \\
(\mu \mathrm{g})\end{array}$ & $\begin{array}{l}\text { remifentanil } \\
(\mu \mathrm{g})\end{array}$ & $\begin{array}{l}\text { ketamine } \\
(\mathrm{mg})\end{array}$ & & time & $\begin{array}{l}\text { repivacaine } \\
(0.2 \% \\
300 \mathrm{ml})\end{array}$ & $\begin{array}{l}\text { repivacaine } \\
(0.75 \% \text {, } \\
30 \mathrm{ml})\end{array}$ & $\begin{array}{l}\text { fentanil } \\
(0.1 \mathrm{mg} / \\
2 \mathrm{ml})\end{array}$ & $\begin{array}{l}\text { droperidol } \\
(25 \mathrm{mg} / \\
10 \mathrm{ml})\end{array}$ & $\begin{array}{l}\text { saline } \\
(\mathrm{ml})\end{array}$ & $\begin{array}{l}\text { injection } \\
\text { (ml/hour) }\end{array}$ & $\begin{array}{l}\text { weight } \\
(\mathrm{kg})\end{array}$ \\
\hline 1 & 400 & 1,360 & 60 & - & - & & & & & & & 66 \\
\hline 2 & 350 & 1,050 & - & - & - & & & & & & & 68 \\
\hline 3 & 500 & 620 & - & - & - & & & & & & & 59 \\
\hline 4 & 275 & 580 & - & - & - & & & & & & & 50 \\
\hline 5 & 150 & 1,437 & - & - & Post & + & - & - & - & - & 4 & 56 \\
\hline 6 & 200 & $2,775.48$ & - & - & Post & + & - & - & - & - & 4 & 66 \\
\hline 7 & 100 & $3,652.62$ & - & - & Post & $200 \mathrm{ml}$ & - & $20 \mathrm{ml}$ & $2 \mathrm{ml}$ & 78 & 4 & 64 \\
\hline 8 & - & $2,043.36$ & - & - & Post & + & + & & & & 4 & 43 \\
\hline 9 & 400 & $3,652.62$ & - & 70 & Post & - & - & $60 \mathrm{ml}$ & $3 \mathrm{ml}$ & 40 & 1 & 102 \\
\hline 10 & 400 & 849.15 & - & 40 & Post & + & - & - & - & - & 4 & 51 \\
\hline 11 & 500 & $1,862.5$ & - & - & Post & - & - & $60 \mathrm{ml}$ & $3 \mathrm{ml}$ & 40 & 1 & 50 \\
\hline 12 & 200 & 1,540 & - & - & Post & + & + & - & - & - & 4 & 50 \\
\hline 13 & 400 & $4,716.8$ & - & - & Post & + & + & - & - & - & 4 & 64 \\
\hline 14 & - & $1,464.01$ & - & - & - & & & & & & & 53.5 \\
\hline 15 & 200 & $1,528.82$ & - & - & Post & + & + & - & - & - & 4 & 54.6 \\
\hline 16 & 500 & $5,841.5$ & - & - & Post & - & - & $60 \mathrm{ml}$ & $3 \mathrm{ml}$ & 40 & 1 & 53 \\
\hline
\end{tabular}

Post $=$ Postoperative

and the combination of epidural injections varied. The level of catheter insertion was Th6, and the level of analgesia was from Th4 to Th12. These aforementioned factors associated with anesthesiology might have been responsible for PRI and suggested that lowering the doses of local anesthetics or opioids was important for the management of respiratory compromise in patients with MG [4].

\section{References}

1 Kataoka H, Kiriyama T, Kawaguchi T, Sawa N, Sugie K, Horikawa H, Tojo T, Ueno S: Preoperative low-dose steroid can prevent respiratory insufficiency after thymectomy in generalized myasthenia gravis. Eur Neurol 2014; $72: 228-233$
Finally, all but one patient received invasive mechanical ventilation. The other patient was given preoperative steroids and received noninvasive mechanical ventilation. Future studies similar to ours should include factors associated with anesthesiology in addition to those related to neurology and surgery. Such studies are expected to more precisely define risk or preventive factors for PRI after thymectomy.

\section{Funding Statement}

There was no funding related to our paper.

\section{Disclosure Statement}

The authors report no competing interest related to our paper.
2 Olanow CW, Wechsler AS, Roses AD: A prospective study of thymectomy and serum acetylcholine receptor antibodies in myasthenia gravis. Ann Surg 1982;196:113-121.

3 Chevalley C, Spiliopoulos A, de Perrot M, Tschopp JM, Licker M: Perioperative medical management and outcome following thymectomy for myasthenia gravis. Can J Anaesth 2001;48:446-451.
4 Sungur Ulke Z, Yavru A, Camci E, Ozkan B, Toker A, Senturk M: Rocuronium and sugammadex in patients with myasthenia gravis undergoing thymectomy. Acta Anaesthesiol Scand 2013;57:745-748. 